Gorontalo Accounting Journal
https://jurnal.unigo.ac.id/index.php/gaj
Vol. 4, No. 2, October 2021
P-ISSN: 2614-2074, E-ISSN: 2614-2066
Gatolontialo
Nationally Accredited Journal, Decree No.36/E/KPT/2019 Sinta 4

\title{
Implementasi Model Pentahelix Dalam Pengembangan UMKM Dimasa Pandemi Covid-19
}

\author{
Parmin Ishak ${ }^{1}$, Nur Lazimatul Hilma Sholehah ${ }^{2}$ \\ 1,2Universitas Ichsan Gorontalo/Jl.Ahmad Nandjamudin, No 17 Kota Gorontalo/Indonesia \\ Email: parminishak72@gmail.com¹,nurlazimatul72@gmail.com²
}

Citation: Ishak, P. \& Sholehah, N. L. H. (2021). Implementasi Model Pentahelix Dalam Pengembangan UMKM Dimasa Pandemi Covid-19. Gorontalo Accounting Journal 4 (2), 207224. DOI: $10.32662 /$ gaj.v4i2.1726

\section{Artikel info}

\section{Artikel history:}

Received: 17-08-2021

Revised: 08-10-2021

Accepted: 19-10-2021

\section{Keywords:}

Pentahelix;

UMKM
Abstract. This study aims to determine the extent of the implementation of the pentahelix model in the development of SMEs during the COVID-19 pandemic in Wonosari District. Data was collected through interviews, documentation and literature study. The results of this study indicate that the development of SMEs in Wonosari District using the pentahelix model has involved five stakeholders, namely the government, academia, community, business and media. Although the five stakeholders have not been optimal in carrying out their respective roles. What is lacking in the pentahelix model is the coordination between stakeholders which is still conditional. This should be a concern for the government as the leading sector to coordinate all stakeholders. As well as the need for monitoring and evaluation from the government in carrying out the program. This paper is expected to contribute to the development of SMEs in the Wonosari sub-district.

\begin{abstract}
Abstrak. Penelitian ini bertujuan untuk mengetahui sejauh mana implementasi model pentahelix dalam pengembangan UMKM dimasa pandemi covid-19 di Kecamatan Wonosari. Pengumpulan data dilakukan melalui metode wawancara, dokumentasi dan studi kepustakaan. Hasil penelitian ini menunjukkan bahwa dalam pengembangan UMKM di Kecamatan Wonosari menggunakan model pentahelix telah melibatkan lima stakeholder yaitu pemerintah, akademisi, komunitas, bisnis dan media. Meskipun lima stakeholder tersebut belum optimal dalam menjalankan perannya masingmasing. Yang menjadi kekurangan dalam model pentahelix adalah koordinasi antar stakeholder yang masih bersifat kondisional. Hal ini harus menjadi perhatian bagi pemerintah selaku leading sektor untuk mengkoordinasikan seluruh stakeholder. Serta perlu adanya monitoring dan juga evaluasi dari pemerintah dalam menjalankan programnya. Karya tulis ini diharapkan dapat berkontribusi terhadap perkembangan UMKM diwilayah Kecamatan Wonosari.
\end{abstract}

Coresponden author: parminishak72@gmail.com 


\section{Pendahuluan}

Pandemi covid-19 memberikan dampak pada ketidakstabilan ekonomi termasuk pada UMKM. Secara umum, mayoritas dari para pelaku UMKM mengalami penurunan pendapatan bahkan kebangkrutan akibat adanya pandemi covid-19 (Sugiarti, Sari \& Hadiyat, 2020). Aspek utama yang sangat berdampak bagi pelaku UMKM salah satunya adalah terjadinya penurunan jumlah penjualan yang membuat kondisi keuangan UMKM mengalami krisis.

Penularan virus corona yang demikian cepat dan masif telah memaksa pemerintah menerapkan pembatasan sosial berskala besar (PSBB). Adanya kebijakan PSBB ini sangat dirasakan oleh UMKM Di Indonesia. Berdasarkan data dari Kementerian Koperasi di paparkan bahwa ada 1.785 koperasi dan 163.713 pelaku usaha kecil dan menengah (UMKM) yang terdampak covid-19 (Aisyah, 2020). Dan salah satu sektor UMKM yang paling terdampak corona yakni sektor usaha makanan dan minuman. Sedikitnya ada 39,9\% UMKM yang memutuskan mengurangi stok barang selama PSBB, sementara 16,1\% UMKM memilih untuk mengurangi karyawan akibat toko yang harus tutup. Kondisi seperti ini juga dialami oleh UMKM di Provinsi Gorontalo. Setidaknya ada sekitar 2.270 UMKM yang terdapat di Kabupaten Gorontalo Utara, Boalemo dan juga Pohuwato yang nyaris gulung tikar karena turut terdampak virus corona.

Kian memburuknya perekonomian Indonesia yang diakibatkan pandemi covid-19 ini memerlukan upaya percepatan dalam hal recovery. Dengan melihat jumlah UMKM di Indonesia yang begitu banyak sudah sepatutnya pemerintah turut andil dalam menyusun berbagai skema program pemulihan ekonomi nasional melalui upaya membangkitkan usaha mikro kecil menengah (UMKM)). Berbagai upaya dalam pemulihan ekonomi nasional ini tentu saja tidak terlepas dari beberapa peran sektor lain seperti academy, business, community, government dan media atau yang dikenal dengan istilah Pentahelix (Nurmalia, 2018) .

Pendekatan strategis pentahelix saat ini sangat dibutuhkan untuk mengembangkan UMKM dengan melibatkan partisipasi dari berbagai pihak demi terwujudnya kemajuan UMKM. Dalam pengembangan UMKM sendiri perlu kerjasama antara para stakeholder, unsur pemerintah mempunyai political power untuk bagaimana merumuskan sebuah kebijakan melalui keputusan sementara masyarakat atau komunitas disebut sebagai social power. Konsep sinergitas pentahelix ini menjadi urgen dilakukan untuk menghindari adanya overlap kebijakan dan program antar pihak-pihak yang berkepentingan dalam penyelenggaraan pemulihan ekonomi pasca pandemi.

Hasil penelitian mengenai model pentahelix ini sudah cukup banyak di lakukan diberbagai negara. Untuk di Indonesia penelitian tentang model pentahelix masih sangat kurang dilakukan, terutama penelitian yang berfokus pada pengembangan UMKM. Beberapa penelitian tentang pentahelix hanya berfokus ke sektor pariwisata saja. Padahal dimasa pandemi covid-19 seperti sekarang ini, UMKM justru perlu mendapatkan perhatian yang ekstra dalam rangka memulihkan ekonomi nasional. Selain fokus penelitian kepada pengembangan UMKM yang masih kurang, penelitian dengan model pentahelix ini lebih banyak dilakukan pada sektor industry. Sehingga peneliti akan melakukan penelitian di sektor yang berbeda yaitu sektor UMKM. Dengan melakukan penelitian di sektor UMKM ini di harapkan dapat menghasilkan hal-hal baru atau temuan-temuan baru yang dapat dijadikan sebagai bahan rekomendasi kepada pemerintah dalam upaya akselerasi pemulihan ekonomi nasional.

Berdasarkan fenomena tersebut maka yang menjadi tujuan utama penelitian adalah mengetahui Implementasi Model Pentahelix Dalam Pengembangan UMKM Dimasa Pandemi Covid-19 


\section{Tinjauan Teoritis}

Pandemi covid-19 memberikan dampak buruk pada keberlangsungan kehidupan ekonomi di Indonesia khususnya bagi pelaku UMKM. Penelitian Thaha (2020) menjelaskan bahwa 163.713 pelaku UMKM pada sektor makanan dan minuman terkena dampak pandemi covid-19. Hasil laporan penelitian tersebut ditambah dengan data dari Kemenkop UMKM yang melaporkan bahwa 56\% pelaku UMKM mengalami penurunan omset penjualan, 22\% pada aspek pembiayaan, 15\% pada aspek distribusi barang dan 4\% mengalami kesulitan mendapatkan bahan baku mentah.

Penelitian Soetjipto (2020) menjelaskan bahwa penyebab omzet dari pelaku UMKM mengalami penurunan disebabkan oleh 63\% daya beli masyarakat yang menurun, 46\% konsumen takut membeli disertai adanya aturan PSBB dan 42\% adanya aturan jam operasional toko. Dengan adanya penurunan omzet tersebut $33 \%$ pelaku UMKM memilih untuk menghentikan produksinya, 19\% menghabiskan stok barang yang dikembalikan, 8\% melakukan produksi berdasarkan pesanan dan $27 \%$ membuka dagangan dengan protocol kesehatan yang ketat.

\section{Model Pentahelix}

Awalanya mentri pariwisata Arief Yahya mencanangkan model pentahelix yang dituangkan dalam Peraturan Menteri Pariwisata Republik Indonesia Nomor 14 Tahun 2016 tentang Pedoman Destinasi Pariwisata Berkelanjutan bahwa untuk menciptakan, memastikan kualitas aktivitas, fasilitas, pelayanan dan untuk menciptakan pengalaman dan nilai manfaat kepariwisataan agar memberikan keuntungan dan manfaat pada masyarakat dan lingkungan maka diperlukan pendorong sistem kepariwisataan melalui optimasi peran business, government, community, academic, and media (Pedoman Destinasi Pariwisata Berkelanjutan, 2016).

Sebelum lahirnya model pentahelix, ada model yang telah dikembangkangkan yakni Model triplehelix dimana model ini sebelumnya merupakan rekomendasi dalam mengembangkan ekonomi, namun karena persaingan pasar yang lebih kompetitif dan bertujuan mengembangkan perusahaan dan ekspor ke pasar dunia maka lahirlah model terbarunya yakni quadruplehelix dimana merupakan rekomendasi untuk kemakmuran perusahaan (Veckie, 2015). Model quadruplehelix adalah hasil pengembangan dari model triplehelix yang mengintegrasikan inovasi, pengetahuan dan civil society. Ada empat stakeholder yang berkolaborasi dalam model pentahelix yakni Perusahaan (Business), Pemerintah (Government), Akademisi (academician), dan masyarakat sosial (civil society) (Sutapa, 2014).

Persaingan akses pasar dunia dan proses globasasi yang semakin pesat, ahirnya model diatas disempurnakan dengan melibatkan media dan menjadi komponen tambahan dalam hal mendukung pengembangan ekonomi dan model ini disebut dengan model pentahelix. Media dianggap merupakan elemen yang mampu menjembatani setiap pemasok dan investor serta membuka pasar luar negri. Ada lima stakeholder yang terlibat dalam mengembangkan UMKM berdasarkan model pentahelix yakni Perusahaan (Bussiness), Komunitas (Community), Akademisi (Academic), Pemerintah (Government), dan Media (Media) (Saputri, 2020).

Model pentahelix ini dapat diterapkan untuk membangkitkan UMKM di masa pandemi, hal ini dikarenakan UMKM tidak akan bangkit dan betumbuh besar jika stakeholder dan pemegang kepentingan tidak saling berkoordinasi dan berkolaborasi, dalam konteks ini pemerintahlah yang menjadi leading sektor dalam menggerakan ke lima stakeholder ini, karena pemerintah memiliki kekuatan penuh dalam pengambilan kebijakan. 


\section{Penelitian Terdahulu}

Penelitian mengenai model pentahelix telah beberapa kali di lakukan di Indonesia. Namun sejauh pengamatan peneliti belum ada penelitian yang secara spesifik membahas tentang implementasi model pentahelix dalam pengembangan UMKM. Meski demikian ada beberapa hasil penelitian yang relevan dan dapat dijadikan rujukan dalam penelitian ini. Salah satunya adalah penelitian yang dilakukan oleh (Marpaung, 2021) terkait model quadruple helix dalam pengembangan UMKM. Hasil penelitian ini menunjukkan bahwa model quadruple helix belum bisa dilaksanakan dengan maksimal dalam pengembangan pengelola pisang saledi di Kabupaten Aceh Tenggara karena belum jelasnya definisi dan konsep pengembangan UMKM pengelola pisang sale dikalangan stakeholders sendiri. Selain itu, masalah regulasi yang belum jelas dan mempunyai payung hukum membuat stakeholders utama yaitu pemerintah daerah ragu dalam menjalankan pengembangan UMKm di daerahnya. Sedangkan dalam konsep quadruple helix semua stakeholders berperan aktif dalam konsep negara Indonesia dengan pemerintah daerah sebagai leader.

Penelitian selanjutnya adalah penelitian yang dilakukan oleh (Yunas, 2019). Hasil penelitian menunjukkan bahwa akademisi pada model pentahelix berperan sebagai konseptor, sektor swasta berperan sebagai enabler, komunitas berperan sebagai akselerator, pemerintah berperan sebagai regulator sekaligus kontroler dan media berperan sebagai expender.

\section{Metode Penelitian}

Penelitian ini berusaha mendeskripsikan gambaran yang senyatanya dari fenomena yang tampak pada implementasi model pentahelix dalam pengembangan UMKM. Ditinjau dari jenis data yang digunakan, jenis penelitian yang digunakan dalam penelitian ini adalah pendekatan kualitatif dengan metode deskriptif. Penggunaan metode ini diharapkan mampu menghasilkan uraian secara mendalam tentang ucapan, tulisan atau perilaku yang dapat diamati dari individu, kelompok, masyarakat maupun organisasi tertentu (Sugiyono, 2018).

Penelitian ini menggunakan prosedur analisis data kualitatif model Miles dan Huberman dalam (Lexy $j, 2017$ ) yakni aktivitas dalam analisis data kualitatif dilakukan secara interaktif dan berlangsung secara terus menerus sampai tuntas. Aktivitas dalam analisis data yaitu yang pertama Reduksi Data, Reduksi data berarti merangkum, memilih hal-hal yang pokok, memfokuskan pada hal-hal yang penting, dicari tema dan polanya. Dengan demikian data yang telah direduksi akan memberikan gambaran yang lebih jelas dan mempermudah peneliti untuk melakukan pengumpulan data. Yang kedua adalah Penyajian Data, Penyajian data dilakukan dengan bentuk uraian singkat, bagan, hubungan antar kategori dan sejenisnya. Penyajian data adalah hal yang akan memudahkan untuk merencanakan kerja selanjutnya berdasarkan apa yang telah dipahami. Dan yang terakhir adalah verifikasi/ kesimpulan, Verifikasi/kesimpulan merupakan temuan baru yang sebelumnya belum pernah ada. Temuan yang datanya berupa deskripsi atau gambaran suatu objek yang belum jelas setelah diteliti akan menjadi jelas.

\section{Hasil Dan Pembahasan}

Kecamatan Wonosari memiliki 70 warung makan dengan 1 unit motel/losmen dan 1 unit koperasi industri kecil dan kerajinan rakyat serta 5 unit koperasi lainnya. Selain itu, terdapat pula 3 minimarket dengan 411 warung kelontong dan juga 1 rumah makan. Daftar pertanyaan wawancara merupakan sebuah data primer yang sangat penting dalam menunjang pelaksanaan penelitian. Dalam Model Pentahelix terdapat 5 unsur yang digunakan yaitu 
pemerintah, akademisi, bisnis, komunitas dan juga media. Untuk mengetahui lebih mendalam mengenai implementasi model pentahelix dalam pengembangan UMKM di Kecamatan Wonosari, berikut hasil wawancara peneliti bersama informan.

\section{Pemerintah}

Usaha Mikro Kecil dan Menengah (UMKM) merupakan salah satu pilar utama perekonomian dimana dengan adanya UMKM dapat membantu lapangan kerja baru dan meningkatkan devisa negara melalui pajak badan usaha. Pasal 33 ayar 4 UUD 1945 menegaskan bahwa UMKM merupakan bagian dari perekonomian nasional yang berwawasan kemandirian dan memiliki potensi besar untuk meningkatkan kesejahteraan masyarakat. Berbagai upaya dilakukan oleh pemerintah untuk meningkatkan UMKM di setiap daerah dimasa pandemi. Peran pemerintah sangatlah dibutuhkan untuk memberikan stimulasi kepada para pelaku usaha yang berdasarkan peraturan yang berlaku. Sebagaimana yang diungkapkan ibu Rita yang mengatakan bahwa ....

"Saat ini pemerintah sudah cukup serius dalam meningkatkan UMKM ditengah pandemi covid-19. Hal ini bisa dilihat dari berbagai kebijakan yang dibuat oleh pemerintah untuk menyelamatkan sekaligus membantu UMKM dalam mempertahankan serta mengembangkan usahanya" lebih lanjut Ibu Rita menjelaskan bahwa "Di dalam kondisi yang penuh ketidakpastian seperti saat ini, pemerintah terus berkomitmen dengan memberikan bantuan presiden produktif untuk UMKM sebesar 2.4 juta" Kebangkitan perekonomian Indonesia bisa dimulai dari dukungan pemerintah baik berupa pendanaan maupun berupa dukungan teknis lain kepada UMKM. Hal ini diutarakan oleh Ibu Rita yang menyatakan bahwa "Kunci untuk bangkit adalah pendanaan dan juga investasi. Adanya Stimulus dari pemerintah merupakan hal paling penting untuk membantu UMKM agar tidak terlalu terdampak parah dimasa pandemi. Selain itu harus ada perbaikan disemua sisi agar stimulus yang diberikan pemerintah bisa makin optimal dan berdampak luas. Jangan sampai stimulus yang diberikan justru menjadi tidak tepat sasaran, tidak tepat waktu dan juga tidak tepat manfaatnya"

Upaya pemerintah mendukung kemudahan bagi UMKM juga telah ditunjukkan dengan berbagai cara. Seperti yang diungkapkan oleh Ibu Rita bahwa

"Ada banyak upaya yang dilakukan pemerintah untuk mengembangkan UMKM saat ini. Salah satu yang bisa kita rasakan adalah adanya kemudahan dalam memulai sebuah usaha. Seperti penyederhanaan prosedur perijinan, keringanan biaya perijinan bagi pembentukan usaha kecil dan pembebasan biaya perijinan bagi usaha mikro. Lebih lanjut Ibu Rita menjelaskan bahwa "Kemudahan yang diberikan pemerintah tidak hanya pada saat mendirikan usaha saja. Saat usaha telah terbentuk, pemerintah juga hadir dengan memberikan penyederhanaan terhadap administrasi perpajakan. Selain itu, pemerintah juga telah menyediakan bantuan dan pendampingan hukum bagi UMKM sekaligus pelatihan dan juga pendampingan sistem aplikasi pembukuan dan pencatatan keuangan bagi UMKM.

Ditinjau dari sisi kebijakan, dukungan pemerintah terhadap UMKM dapat dilihat dari produk hukum terkait UMKM. Secara eksplisit dukungan pemerintah terhadap UMKM dapat dilihat dalam Perpres Nomor 98 Tahun 2014 tentang 
Perizinan untuk Usaha Mikro dan Kecil. Produk hukum ini bertujuan menambah kuatnya legalitas usaha kecil dan menengah. Izin usaha mikro dan kecil (IUMK) memberikan kepastian dan perlindungan berusaha di lokasi yang telah ditetapkan. Sebagaimana tertulis dalam pasal 2 ayat 4 Perpres Nomor 98 Tahun 2014 untuk pengurusan IUMK, pelaku usaha tidak dikenakan biaya, retribusi serta pengutan lain.

Dukungan dari pemerintah sangat penting bagi pelaku UMKM. Peran pemerintah dalam pengembangan UMKM yang efektif dan optimal diwujudkan sebagai fasilitator, regulator dan katalisator. Sebagai fasilitator pemerintah memiliki peran dalam memfasilitasi UMKM untuk mencapai tujuan pengembangan usaha yang dimiliki oleh UMKM. Apabila UMKM memiliki kelemahan dalam bidang produksi, maka tugas fasilitator adalah memberikan kemampuan UMKM dengan berbagai cara misalnya dengan memberikan pelatihan. Demikian pula jika UMKM lemah dalam hal pendanaan, maka tugas fasilitator adalah membantu mencari jalan keluar agar UMKM mampu mendapat pendanaan yang dibutuhkan dan tetap mempertimbangan prinsip kehati-hatian agar UMKM tidak menjadi ketergantungan.

Untuk menggerakkan UMKM dalam masa penanganan covid-19, ada beberapa fase yang harus dihadapi. Pertama, rescue adalah fase dimana bantuan ekonomi harus diberikan kepada masyarakat dan pihak yang terkena dampak covid-19. Pada fase ini pemerintah harus mempertimbangkan adanya trade-off antara kesehatan dan ekonomi. Kedua, stability yaitu fase dimana ketika masyarakat mampu beraktivitas seperti biasa dengan menerapkan protocol kesehatan. Hal tersebut juga akan menimbulkan pergeseran ketakutan menjadi kesadaran dan ditandai dengan meningkatnya aktivitas menggunakan bantuan teknologi. Ketiga adalah recovery dimana ketika masyarakat mulai berdamai dengan covid-19 dan melakukan kegiatan dengan pola new normal. Dalam mencapai fase tersebut UMKM membutuhkan imunitas selama tahap stability. Oleh karena itu, perlu ada point penting yang harus dibangun oleh pelaku UMKM dan pemangku kepentingan.

Melihat kondisi dan permasalahan yang dihadapi oleh UMKM disaat pandemi tentunya memberikan dampak pada menurunnya tingkat kesejahteraan masyarakat khususnya para pelaku UMKM. Untuk itu diperlukan peran pemerintah baik pusat maupun daerah untuk menjamin kesejahteraan masyarakat. Dengan memberikan bantuan serta fasilitasi dalam penyaluran bantuan bagi pelaku usaha mikro (BPUM) diharapkan dapat membantu memberikan kesejahteraan bagi pelaku usaha mikro yang terdampak pandemi. Selain berperan sebagai fasilitator, pemerintah juga memiliki peran sebagai regulator yaitu dengan membuat kebijakan-kebijakan sehingga mempermudah usaha UMKM dalam mengembangkan usahanya. Oleh karena itu, pemerintah baik pusat maupun daerah memberikan fokusnya untuk menjaga supaya UMKM tetap bertahan dan dapat kembali membantu pemulihan ekonomi nasional. Upaya tersebut dapat dilakukan dengan memberikan perlindungan hukum bagi UMKM khususnya ekonomi Mikro. Dimasa pandemi seperti sekarang ini dapat dilihat bahwa pemerintah pusat dan daerah saling bersinergi membantu para pelaku usaha mikro dengan menetapkan sejumlah kebijakan seperti PERMENKOP Nomor 6 Tahun 2020 tentang pemberian bantuan bagi usaha mikro. Usaha yang dilakukan oleh pemerintah melalui kebijakan tersebut dimaksudkan supaya usaha mikro bisa tetap bertahan dengan pemberian bantuan stimulus ekonomi berupa permodalan bagi pelaku usaha mikro.

Selanjutnya peran pemerintah sebagai katalisator pengembangan UMKM adalah dengan mempercepat proses berkembangnya UMKM menjadi fast moving 
enterprise. Keterlibatan pemerintah daerah dalam keseluruhan proses perubahannya tidak boleh dilakukan karena keterlibatan peran pemerintah yang terlalu banyak dalam kegiatan perekonomian akan menyebabkan perekonomian menjadi tidak efisien lagi sebab pasar tidak dapat bergerak lagi secara alami. Untuk dapat menjalankan perannya sebagai katalisator, pemerintah melakukan berbagai langkah seperti pemberdayaan komunitar kreatif untuk produktif bukan konsumtif, memberikan penghargaan kepada UMKM, prasarana intelektual bagi UMKM dan permodalan. Tujuan pemberian bantuan permodalan dan pendanaan adalah untuk merekonstruksi usaha bisnis agar lebih produktif yang pada gilirannya mampu menjadi usaha yang kompetitif.

Peran pemerintah dalam pemenuhan kebutuhan modal bagi pelaku UMKM tentu saja tidak hanya terbatas sebagai pihak yang menyediakan informasi belaka. Pemerintah seyogyanya memberikan dukungan yang lebih nyata akan keterbatasan pelaku UMKM dalam hal modal usaha tidak terbatas pada kebutuhan jaminan sebagai salah satu syarat utama yang dibutuhkan dalam mendapatkan modal tersebut.

\section{Akademisi}

Dalam situasi pandemi seperti sekarang ini, menurut Kemenkop UKM ada sekitar 37.000 UMKM yang memberi laporan terkena dampak dari covid-19 seperti penurunan penjualan, permasalahan pada aspek pembiayaan, masalah distribusi barang serta sulitnya mendapat bahan baku mentah. Masalah - masalah tersebut semakin meluas karena adanya Pembatasan Sosial Berskala Besar (PSBB) yang ditetapkan beberapa wilayah di Indonesia. Keadaan ini tentunya menjadi suatu tantangan sekaligus peluang bagi pemerintah untuk menjaga eksistensi dari UMKM. Bukan hanya pemerintah saja melainkan tanggung jawab dari seluruh masyarakat Indonesia termasuk perguruan tinggi dan mahasiswa yang merupakan agent of change yang diharapkan mampu merubah tantangan yang ada menjadi sebuah peluang untuk bisa mengembangkan ekonomi kerakyaratan melalui usaha mikro di tengah pandemi covid-19 ini. Sebagaimana yang dijelaskan oleh Bapak Huda yang menyatakan bahwa

"Untuk menghadapi perubahan situasi seperti sekarang ini, UMKM harus mampu beradaptasi dengan cepat. Salah satunya melalui digitalisasi. Digital disini bukan sekedar masuk saja, tetapi juga mempersiapkan diri untuk setiap perubahan dan juga dampaknya nanti..."Lebih lanjut Bapak Huda menjelaskan bahwa "walaupun kita bicara tentang digitalisasi, sebagai akademisi kita juga tetap harus melakukan pendampingan. Pendampingan disini bisa bermacammacam bentuknya, bisa melalui training,coaching,gathering sampai dengan konsultasi. Yang intinya kita harus membantu UMKM untuk siap kearah digitalisasi"

Upaya-upaya kongkrit tersebut merupakan amanat dari UU No. 20 Tahun 2008 tentang UMKM yang menyatakan bahwa UMKM merupakan sektor yang menggerakkan perekonomian kerakyatan maka untuk mendukung peran strategis UMKM tersebut perlu dilakukan pemberdayaan UMKM secara komprehensif. Wujud nyata dari dukungan perguruan tinggi adalah dengan memberikan ilmu kewirausahaan. Bukan hanya berupa teori namun juga dalam pengaplikasiannya. Sebagaimana yang diungkapkan oleh Bapak Huda bahwa

"......UMKM akan dilibatkan di kampus dengan memanfaatkan Science Techno Park" Lebih lanjut Bapak Huda menjelaskan bahwa "upaya untuk mendigitalisasi proses bisnis dari pelaku UMKM terutama yang masih asing dengan perkembangan teknologi ini masih cukup sulit karena sering terbentuk dengan pola pikir pelaku 
usahanya sendiri, oleh karena itu sebagai bentuk pelaksanaan tri dharma perguruan tinggi, akademisi akan memberikan dukungan dalam bentuk pelatihan, pembimbingan, pendapatan dan kemudahan bagi pelaku UMKM..."

Transparansi UMKM ke sektor digital tidak boleh hanya sekedar memanfaatkan akses internet, namun juga harus mammpu menjaga suplainya. Hal ini serupa dengan penjelasan dari bapak Huda yang menyatakan bahwa

"kalau UMKM masuk ke market online, pasar mereka akan berskala nasional. Jadi kalau UMKM tidak memiliki manajemen respon yang cepat terhadap permintaan pasar, UMKM juga akan kehilangan kredibilitasnya"...lebih lanjut Bapak Huda menjelaskan bahwa "sebagai salah satu bentuk pengabdian kepada masyarakat sekaligus dukungan terhadap program pemerintah untuk penguatan UMKM, perguruan tinggi melakukan pembinaan pada usaha-usaha masyarakat yang tersebar di provinsi gorontalo pada umumnya. Dukungan yang dilakukan oleh akademisi ini menyangkut beberapa aspek pengembangan usaha seperti optimasi proses produksi, perbaikan pengemasan, pengembangan jalur distribusi, strategi pemasaran sampai pada pengenalan dan pelatihan teknologi dalam proses pengembangan usaha" Tidak hanya itu, Bapak Huda juga menjelaskan bahwa "dukungan yang diberikan tidak hanya terbatas sampai pada bagaimana produk bisa dipasarkan di marketplace namun juga sampai pada menjembatani pelaku usaha dengan dinas terkait".

Akademisi pada model pentahelix ini berperan sebagai konseptor. Seperti melakukan standarisasi proses bisnis serta sertifikasi produk dan keterampilan sumber daya manusia. Akademisi dalam hal ini merupakan sumber pengetahuan dengan konsep, teori-teori terbaru dan relevan dengan bisnis yang dikembangkan pelaku UMKM untuk mendapatkan keunggulan kompetitif yang berkelanjutan. Sehingga peran akademisi disini adalah berbagi informasi dengan pelaku stakeholder.

Sesuai dengan indikator pada model pentahelix, akademisi disini telah menjalankan peran sebagai konseptor. Berdasarkan hasil evaluasi yang telah dilakukan, akademisi tidak hanya berperan sebagai konseptor tetapi juga berperan sebagai actor dalam berbagi informasi dengan para pelaku usaha tentang informasi yang sifatnya baru dan relevan. Akademisi sebagai actor yang sering terlibat dalam kebijakan, memiliki kepakaran dan merupakan lembaga penelitian yang berperan dalam implementasi kebijakan. Dalam pengembangan UMKM, akademisi dalam hal ini perguruan tinggi dan lembaga penelitian memainkan peran yang sangat penting dalam membentuk masyarakat yang berbasis pengetahuan. Kapasitas akademisi adalah untuk membentuk masyarakat melalui penyediaan tenaga kerja terampil yang dibutuhkan sehingga pengetahuan ekonomi dapat berkembang. Disamping itu, mempersiapkan mahasiswa untuk berfikir kritis dan mengembangkan bakat dan menghasilkan pengetahuan serta keterampilan yang inovatif, giat dan berwirausaha.

Akademisi yang merupakan bagian dari cendekiawan dijabarkan dalam 3 bentuk peranan yaitu pertama, peran pendidikan ditujukan untuk mendorong lahirnya generasi kreatif infonesia dalam pola pikir yang mendukung tumbuhnya karsa dan karya dalam industry kreatif. Kedua, peran penelitian dilakukan untuk memberikan masukan tentang model kebijakan pengembangan industry kreatif dan instrument yang dibutuhkan serta menghasilkan teknologi yang mendukung cara kerja dan penggunaan sumber daya yang efisien dan menjadikan industry 
kreatif nasional yang kompetitif. Ketiga, peran pengabdian kepada masyarakat dilakukan untuk membentuk masyarakat dengan institusi/tatanan sosial yang mendukung tumbuh suburnya industry kreatif nasional.

Kontribusi akademisi dalam menjalankan tri dharma perguruan tinggi dalam hal ini adalah penelitian dan pengabdian masyarakat. Penelitian yang telah dilakukan oleh perguruan tinggi bersama stakeholder lainnya akan menjadi suatu langkah yang seharusnya mampu diarahkan sebagai bentuk penyebarluasan pengetahuan baru, sehingga hasil dari penelitian mampu membawa dampak langsung pada pengembangan UMKM. Inovasi akan menjadi kata kunci dalam keterlibatan akademisi, pada penyebaran informasi maupun penerapan teknologi, kewirausahaan melalui kolaborasi dan kemitraan yang bermanfaat antara akademisi, pemerintah, bisnis, komunitas dan media massa.

\section{Bisnis}

Pandemi covid-19 tidak hanya mengancam sektor kesehatan, namun juga mengancam krisis ekonomi global. Dari adanya pandemi corona ini maka dikeluarkanlah PP Nomor 21 Tahun 2020 tentang pembatasan sosial berskala besar dengan maksud untuk membatasi pergerakan orang dan barang dan mengharuskan masyarakat untuk berdiam diri dirumah. Hal ini juga berdampak terhadap terbatasnya operasional UMKM dan berkurangnya konsumen yang berbelanja secara langsung dibandingkan hari biasa. Efek pertama dari pandemi ini adalah beralihnya sistem finansial perusahaan ke zero based budgeting. Kedua adalah adanya pemutusan hubungan kerja (PHK) besar-besaran di berbagai perusahaan. Efek ketiga adalah kekacauan produksi yang dialami berbagai perusahaan. Efek keempat adalah penurunan produktivitas perusahaan dan dampak terakhir adalah runtuhnya perusahaan akibat kebangkrutan yang disebabkan ketidakmampuan perusahaan untuk bertahan di tengah pandemi.

Berkurangnya mobilisasi massa disekitar pasar tentu akan menghambat laju promosi yang akan berpengaruh kepada tingkat penjualan. Untuk mengatasi hal tersebut, pemasaran secara online melalui media menjadi langkah tepat yang harus dilakukan oleh para pelaku usaha. Hal ini sesuai dengan pernyataan bapak Yuyun yang menjelaskan bahwa :

"dalam situasi seperti sekarang ini saya tidak bisa hanya mengandalkan pembeli yang datang langsung ke warung, makanya sekarang saya harus lebih aktif pakai facebook untuk mempromosikan barang saya, karena kalau tidak maka akan susah mendapatkan uang setiap harinya, ya walaupun biaya pulsa data menjadi semakin membengkak tapi ya mau bagaimana lagi mau tidak mau saya harus bisa menyesuaikan dengan kondisi sekarang..."

Pandemi covid 19 membatasi para konsumen untuk membeli produk secara langsung. Adanya pandemi ini juga menyebabkan banyaknya peraturan yang dikeluarkan oleh pemerintah seperti larangan untuk berkerumun dan adanya pembatasan sosial berskala besar (PSBB). Kondisi ini yang menyebabkan para mitra kesulitan dalam melayani konsumen yang biasanya berkumpul di lapak. Hal ini sesuai dengan apa yang dijelaskan oleh bapak Yuyun yang menjelaskan bahwa

"sekarang kan semua kegiatan dari rumah, jadi banyak pembeli yang maunya pesanannya di antar sampai ke rumah. Makanya kami sekarang juga menggunakan aplikasi kayak bravojek dan nujek untuk antar pesanan. Tapikadang juga kami antar sendiri menggunakan motor"

Upaya untuk mengurangi dampak dari permasalahan pelaku UMKM ditengah pandemi adalah dengan memanfaatkan pasar online. Pemasaran secara online 
melalui media merupakan langkah tepat yang harus dilakukan oleh para pelaku usaha. Hal ini pada dasarnya selaras dengan yang disampaikan oleh bapak Yuyun yang menjelaskan bahwa

"bisnis kuliner saat ini memang mengalami krisis yang sangat besar, walaupun kita masih buka kadang juga tidak ada keuntungan...pendapatan hanya cukup untuk membayar gaji karyawan".Lebih dalam bapak Yuyun menjelaskan bahwa "strategi yang bisa kami lakukan ya kami hanya bisa memanfaatkan facebook selebihnya kami belum paham kalau harus menggunakan media apa lagi” Tidak hanya itu, bapak Yuyun juga mengungkapkan bahwa "saat ini yang bisa kita lakukan ya hanya bertahan, beradaptasi dan melakukan inovasi biar kita tidak bangkrut"

Pemerintah Indonesia berupaya untuk mengatasi permasalahan tersebut dengan mengeluarkan beberapa kebijakan khususnya di bidang perekonomian agar permasalahan pandemi tidak mengakibatkan resesi ekonomi yang berkepanjangan. Salah satu kebijakan yang dikeluarkan oleh pemerintah adalah adanya dana bantuan BPUM untuk UMKM. Hal ini sesuai dengan penjelasan bapak Yuyun bahwa

"selama ini sebenarnya pemerintah sudah menyiapkan strategi berupa bantuan BPUM, tapi ya kadang yang dapat justru bukan yang tepat sasaran"

Bisnis pada model pentahelix berperan sebagai enabler. Bisnis merupakan entitas yang melakukan proses bisnis dalam menciptakan nilai tambah dan mempertahankan pertumbuhan yang berkelanjutan. Bisnis berperan sebagai enabler yang menghadirkan infrastruktur TIK dengan mendukung perubahan pada sumber daya manusia, proses bisnis dan produk yang dihasilkan ke era digital. Dengan adanya perubahan ke era digital maka dapat membantu UMKM menjadi lebih efektif, efisien dan produktif. Dalam program pengembangan UMKM yang memiliki peran sebagai bisnis adalah pelaku UMKM itu sendiri dan juga perusahaan swasta.

Pelaku UMKM memainkan peran sebagai penentu strategi dalam mengembangkan bisnis. Pelaku UMKM ini adalah sebagai entitas utama dalam mengembangkan UMKM karena mereka menjalankan roda ekonomi melalui usaha yang digeluti. Kreativitas yang dimiliki oleh pelaku UMKM merupakan modal utama dan nilai jual utama dari produk yang mereka jual. Kreativitas pelaku UMKM harus selalu ditingkatkan agar dapat memenuhi permintaan pasar dan bersaing. Dengan adanya model pentahelix maka dapat menggerakkan para pelaku UMKM untuk lebih meningkatkan kreativitas, ide, dan keterampilan melalui kolaborasi yang tercipta dengan berbagai stakeholder.

Untuk mengembangkan program dimasa pandemi, sejumlah kendala masih dihadapi oleh para pelaku UMKM diantaranya adalah keterbatasan modal dan akses permodalan bank. Untuk mengatasi hal ini pemerintah mengeluarkan kebijakan berupa bantuan presiden BPUM untuk dapat membantu meringankan masalah modal dari pelaku UMKM ditengah ketidakpastian lingkungan usaha. Para stakeholder yang berperan sebagai bisnis pada program pengembangan UMKM pada dasarnya sudah menjalankan peran dengan baik sesuai dengan indikator pada model pentahelix. Hal tersebut dapat terlihat karena actor yang mewakili bisnis telah menjalankan peran sebagai enabler dengan mendukung para pelaku usaha untuk mengembangkan usahanya melalui bantuan modal, meningkatkan kemampuan sumber daya manusia melalui pelatihan guna mendukung perubahan proses bisnis ke era digital. 


\section{Komunitas}

Komunitas adalah suatu kelompok sosial di suatu masyarakat yang terdiri dari beberapa individu yang saling berinteraksi di lingkungan tertentu dan umumnya para anggotanya memiliki ketertarikan yang sama, misalnya kesamaan minat atau kesamaan profesi. Suatu komunitas terbentuk karena adanya keinginan dari para anggotanya untuk mencapai tujuan tertentu yang telah disepakati bersama. Selain itu, komunitas juga bertujuan untuk saling memberikan bantuan sesama anggotanya sehingga dapat berkembang bersamasama.

Bisnis yang tergabung dalam komunitas dapat memberikan banyak keuntungan dan pengaruh besar. Komunitas bisa memberikan akses untuk bertemu dengan para professional, menemukan rekan satu tujuan, menciptakan kolaborasi atau menemukan mentor yang membawa bisnis semakin berkembang. Komunitas bisa menjadi wadah berbagi dan bertukar pikiran demi kemajuan bisnis masing-masing. Komunitas juga bisa memberi pengaruh besar terhadap perkembangan usaha, layaknya support system komunitas bisa menjadi sebuah forum untuk saling berbagi pengalaman hingga akses untuk mendapatkan informasi mengenai berbagai program pengembangan usaha. Dalam Wawancara dengan bapak Yuyun selaku pelaku usaha menjelaskan bahwa :

"waktu saya ketemu dengan sesama penjual yang kebetulan punya masalah yang sama dengan saya, kita bisa saling cerita. Ya samasama cerita bagaimana cara mengembangkan usaha.." Lebih lanjut bapak Yuyun menjelaskan bahwa "kalau saya sih tidak menggangap penjual lain itu pesaing,,,ya namanya saja jualan, rezeki setiap orang juga sudah ada takarannya. Justru saya berfikirnya pesaing itu bisa menjadi guru untuk kita biar kita bisa banyak belajar.."

Besarnya peran UMKM dalam pengembangan ekonomi nasional telah mendorong pemerintah untuk melakukan reorientasi kebijakan ekonomi nasional dengan mendorong terwujudnya iklim usaha yang akomodatif bagi UMKM. Pemerintah bersama organisasi masyarakat sipil merupakan actor yang paling dominan dalam memberikan dukungan dan bantuan kepada UMKM. Dukungan yang diberikan oleh pemerintah dan OMS ini antara lain pelatihan teknologi, restrukturisasi pinjaman bank, bantuan penyediaan bahan baku, bantuan sosial tunai, bantuan modal, penyuluhan protocol covid-19 dan pelatihan usaha. Hal ini selaras dengan hasil wawancara dengan bapak Yuyun yang menjelaskan bahwa :

"selama ini banyak sekali pelatihan-pelatihan yang diadakan pemerintah untuk pelaku usaha, ya Alhamdulillah kita bisa dapat tambahan ilmu...."Lebih lanjut bapak Yuyun menjelaskan bahwa: "ya harapannya dukungan pemerintah dan komunitas bisa berlangsung dengan baik kedepannya apalagi ditengah pandemi seperti sekarang,

bantuan modal dan pelatihan bagaimana menggunakan teknologi

untuk berjualan sangat kami butuhkan ...."

Komunitas pada model pentahelix berperan sebagai akselerator. Dalam hal ini komunitas merupakan orang-orang yang memiliki minat yang sama dan relevan dengan bisnis yang berkembang. Bertindak sebagai perantara atau menjadi penghubung antar pemangku kepentingan untuk membantu UMKM dalam keseluruhan proses dan memperlancar adopsi proses bisnis di era digital. Komunitas juga memiliki peran untuk mempromosikan produk atau layanan UMKM. Komunitas pada dasarnya merupakan suatu entitas pelaku UMKM yang dibentuk dengan tujuan untuk memenuhi kebutuhan dan mengaktualisasikan keberadaan para anggotanya. 
Komunitas memainkan peran untuk mendukung kontribusi industry dengan jalan membuka akses pada interaksi dunia usaha bersama lingkungan dan mendorong keahlian kreatif serta pendidikan bagi anggota komunitas. Peran komunitas ini berdampak langsung pada pemasaran dan berdampak tidak langsung pada kinerja usaha UMKM. Jika peran komunitas tinggi, penerapan strategi pemasarannya semakin bagus dan berhasil meningkatkan kinerja usahanya dan sebaliknya. Peran komunitas yang tinggi akan berdaya hasil tinggi ketika strategi pemasaran dilakukan secara online atau menjalankan bisnis digital. Media

Kondisi pandemi yang mengakibatkan adanya physical dan social distancing memengaruhi bentuk proses pemasaran yang terjadi. Dimasa pandemi covid-19, konsumen melakukan belanja mengandalkan media online untuk menghindari kontak langsung/kontak fisik dengan pedagang/penjual. Hal ini menginspirasi pelaku UMKM untuk melakukan adaptasi, menyesuaikan perubahan budaya belanja mulai dari komunikasi, distribusi dan pembelian produk pemasaran. Pelaku UMKM perlu memperhatikan dengan baik bagaimana mereka melakukan komunikasi pemasaran terutama dalam penggunaan media pemasaran yang tepat agar konsumen tetap pada standar protocol kesehatan yang telah ditetapkan.

Pemilihan media komunikasi pemasaran dilandaskan pada jenis produk yang akan dipasarkan, target sasaran, waktu pengiriman pesan dan biaya promosi. Diperlukan pertimbangan dalam memilih media komunikasi pemasaran yang efektif. Dengan demikian, para pelaku UMKM harus mempertimbangkan dengan baik pemilihan media yang tepat dalam mempromosikan produknya agar dapat diterima oleh masyarakat. Berdasarkan hasil wawancara dengan bapak Kifli dijelaskan bahwa :

"media massa merupakan satu barometer. Di media massa masih ada yang namanya integritas. Tapi akan Lebih baik lagi jika media sosial dan media massa bisa saling bersinergi untuk membantu mengembangkan UMKM di masa-masa sulit seperti sekarang" Lebih lanjut bapak Kifli menuturkan bahwa : "pendekatan digital seiring perkembangan zaman harus dilakukan sehingga bakal mampu memberikan dampak signifikan bagi UMKM itu sendiri."

Pandemi Covid-19 mengubah perilaku konsumen dan peta kompetisi bisnis yang perlu diantisipasi oleh para pelaku usaha akibat adanya pembatasan kegiatan. Konsumen lebih banyak melakukan aktivitas di rumah dengan memanfaatkan teknologi digital. Sedangkan perubahan lanskap industry dan peta kompetisi baru ditandai dengan empat karakteristik bisnis yaitu hygiene, lowtouch, less-crowd dan low-mobility. Perusahaan atau usaha yang sukses di era pandemi ini merupakan perusahaan yang dapat beradaptasi dengan 4 karakteristik tersebut. Dengan demikian, pelaku usaha termasuk UMKM perlu berinovasi dalam memproduksi barang dan jasa sesuai dengan kebutuhan pasar. UMKM juga perlu menumbuh kembangkan berbagai gagasan dan ide untuk usaha baru yang juga dapat berkontribusi sebagai pemecah masalah sosial ekonomi masyarakat yang diakibatkan oleh pandemi (social entrepreneurship). Hal ini sesuai dengan hasil wawancara yang diungkapkan oleh bapak Kifli yang menjelaskan bahwa :

"caranya untuk bisa tetap bertahan ditengah pandemi adalah memiliki kreatifitas dan inovasi" Tidak hanya itu, bapak Kifli juga menjelaskan bahwa :"Optimisme harus dimiliki semua kalangan untuk mendongkrak ekonomi"

Media massa memiliki peranan yang sangat penting dalam sirkulasi informasi. Artinya peran media massa merupakan suatu hal yang vital dalam mengatasi keterpurukan UMKM akibat wabah covid-19. Media massa memiliki 
fungsi seperti dua mata pisau, satu sisi positif dan satu sisi negative. Dengan adanya media massa juga bisa membantu pemerintah dalam penyebaran informasi agar lebih cepat, akurat dan terpercaya. Berdasarkan hasil wawancara bersama bapak Kifli di jelaskan bahwa :

"sebenarnya pada dasarnya peran media tidak hanya melakukan edukasi atau menyambung lidah pemerintah tapi juga sekaligus menjadi kritik yang baik terhadap pemerintah dalam menjalankan programnya". Lebih lanjut bapak Kifli menjelaskan bahwa :"Sektor UMKM yang digerakkan oleh usaha kecil ini harus mampu eksis meskipun dengan situasi yang serba sulit, bahkan pemerintah pun kan sebenarnya sudah mendongkrak para pelaku usaha dengan berbagai kebijakan misalnya dengan adanya bantuan BPUM, ini semua kan tujuannya agar UMKM bisa bangkit dari keterpurukan. Selebihnya ya tinggal bagaimana para pelaku usaha bisa memanfaatkan media massa untuk mengembangkan usahanya. Karena jalannya kan sudah disediakan oleh pemerintah. bahkan ada pelatihan-pelatihan yang dilaksanakan. Tinggal bagaimana menguatkan sumber daya manusia dari pelaku usaha itu sendiri untuk menghadapi wabah ini..apakah pelaku usaha bisa survive atau tidak.."

Media pada model penta helix berperan sebagai expender. Media berperan dalam mendukung publikasi dalam promosi dan membuat brand image. Dalam program pengembangan UMKM yang mendukung peran media adalah facebook sebagai media untuk promosi dan informasi. Peran media dalam program pengembangan UMKM melalui facebook memuat informasi tentang program pengembangan UMKM, berita-berita tentang usaha dan produk yang jual yang disertakan dengan harga. Terkait dengan peran media, memang cukup banyak media massa namun belum ada yang menjadi media partner pemerintah untuk mengembangkan UMKM. Media massa hanya dilibatkan sebagai pihak penyalur informasi kepada masyarakat ketika penyelenggaraan suatu acara. Pemerintah belum menjadikan media sebagai stakeholder utama dalam mengembangkan UMKM. Pemerintah memandang keterlibatan media terjadi secara otomatis ketika ada suatu acara karena memang media membutuhkan konten informasi yang akan disebarluaskan kepada masyarakat. Padahal hubungan antara media dan keempat actor lainnya terutama pemerintah dapat membentuk sebuah sinergi yang saling menguntungkan. Facebook dapat dikatakan sebagai salah satu e-commerce yang mendukung pelaku UMKM untuk memasarkan produknya. E-commerce sendiri adalah perdagangan elektronik dengan kegiatan jual beli barang/jasa melalui jaringan elektronik terutama internet. Karena dengan mengakses facebook pembeli dapat membeli produk secara online. Hal ini memudahkan pembeli untuk membeli secara online tidak harus mendatangi tempat usaha secara langsung. Dengan adanya facebook ini maka dapat mendukung para UMKM untuk mengembangkan usahanya sebagai sarana promosi produk yang dihasilkan. Selain facebook, media sosial lain juga ikut berpengaruh bagi penyebaran informasi terkait perkembangan UMKM seperti twitter dan instagram. Namun belum banyak masyarakat yang memanfaatkan media sosial tersebut dalam kehidupan sehari-hari. Hal ini menjadi kekurangan bagi pelaku umkm. Karena media sosial pada era digital sangat lekat dengan masyarakat. Jika bisa dimanfaatkan dengan baik maka feedback yang diterima oleh para pelaku UMKM untuk memajukan usahanya melalui dukungan media dan keempat actor lainnya akan optimal. Media sosial mempunyai peran yang strategis pada era digital, karena informasi dapat disebarluaskan serta dapat diterima masyarakat dengan mudah dan cepat. Media sosial telah dimanfaatkan 
secara pribadi oleh pelaku UMKM untuk mengembangkan usahanya. Pemerintah belum mempunyai akun jejaring sosial yang bisa mengunggah informasi, kegiatan maupun mempromosikan UMKM.

Pengembangan UMKM melalui promosi media memang dibutuhkan agar eksistensi UMKM dapat diketahui secara luas oleh publik. Sementara media sendiri memang membutuhkan konten informasi untuk dibagikan kepada masyarakat. Media dapat dijadikan sebagai jendela luar untuk melihat perkembangan UMKM. Terkait hal tersebut, media jelas memegang peran penting untuk menunjukkan reputasi UMKM. Peran ini seharusnya menjadi titik perhatian pemerintah terutama sebagai actor penentu kebijakan pengembangan UMKM. Hal ini menjadi pertimbangan bagi pemerintah untuk dapat menjalin kolaborasi positif dengan media sehingga iklim pemberitaan media massa dapat kondusif.

Peran media dalam program pengembangan UMKM belum berjalan dengan optimal. Apabila media massa dikombinasikan dnegan media sosial dalam pengembangan UMKM maka hal ini dapat memperkuat peran media untuk promosi dan membuat brang image. Apabila pada era yang hampir semuanya bersifat digital. Hal ini dapat menjadi salah satu dampak positif media dalam ikut berkontribusi dalam pengembangan UMKM.

\section{Hubungan Model Pentahelix Dalam Pengembangan UMKM}

Berdasarkan penelitian, terdapat lima pemangku kepentingan (stakeholder) yang berkolaborasi dalam pengembangan UMKM. Berikut penjelasan jenis hubungan antar stakeholder dalam pengembangan UMKM.

\section{Hubungan Pemerintah Dengan Akademisi}

Jenis hubungan antara pemerintah dan akademisi adalah collaborating. Collaborating merupakan tingkatan tertinggi dalam kerjasama antar stakeholder. Pemerintah dengan akademisi perlu meningkatkan jenis hubungan menjadi kolaborasi. Kolaborasi di dukung dengan komitmen waktu yang ekstensif, kepercayaan yang tinggi untuk meningkatkan kapasitas dan saling berbagi resiko. Hal ini diperlukan untuk membantu pemerintah dalam pengembangan program agar berjalan secara optimal. Akademisi sebagai stakeholder yang merupakan sumber pengetahuan dengan teori maupun konsep yang terbaru dan relevan dapat membantu pemerintah jika terdapat hambatan pada saat mengembangkan program. Sehingga pemerintah bisa berbagi risiko dengan akademisi dan bersamasama mencari solusi yang tepat untuk menanganinya.

\section{Hubungan Pemerintah Dengan Bisnis}

Jenis hubungan antara pemerintah dan bisnis adalah collaborating. Ciri-ciri collaborating yakni adanya saling berbagi sumber daya, risiko dan tanggung jawab. Pemerintah dan bisnis perlu menjalin hubungan dengan kolaborasi karena perlu adanya saling berbagi sumber daya, risiko dan tanggung jawab dengan sepenuhnya. Bisnis dapat membantu dalam memberikan bantuan misalnya bantuan modal, fasilitas, pelatihan dan akses untuk mempermudah proses bisnis. Dengan bantuan ini maka perlu adanya koordinasi yang baik antara pemerintah dengan bisnis untuk saling bertanggung jawab sehingga mengerti bantuan apa yang harus diberikan dan sesuai dengan kebutuhan. Serta saling berbagi risiko untuk memecahkan suatu masalah yang menghambat pengembangan program.

\section{Hubungan Pemerintah Dengan Komunitas}

Jenis hubungan antara pemerintah dan komunitas adalah collaborating. Collaborating antara pemerintah dan komunitas untuk meningkatkan hubungan menjadi lebih baik. Dalam collaborating terdapat komitmen waktu yang intensif, kepercayaan yang tinggi saling berbagi tanggung jawab dan risiko. Komunitas yang menaungi para pelaku UMKM dan pemerintah harus memiliki komitmen waktu yang intensif dan kepercayaan yang tinggi. Kepercayaan harus menjadi dasar 
dalam menjalin hubungan. Dimana dalam hal ini komunitas berperan menaungi para pelaku UMKM untuk mendorong para pelaku UMKM berkembang dengan baik, karena komunitas merupakan stakeholder yang paling dekat dengan para pelaku UMKM. Sehingga saling berbagi tanggung jawab dan risiko diperlukan antara pemerintah dan komunitas.

\section{Hubungan Pemerintah Dengan Media}

Jenis hubungan antara pemerintah dan media adalah coordinating. Ciri-ciri coordinating adalah adanya saling berbagi sumber daya yang minimal namun hubungan tetap resmi dengan komitmen waktu sedang. Jenis hubungan coordinating cukup untuk hubungan yang terjadi antara pemerintah dan media. Dengan adanya saling berbagi sumber daya yang minimal namun hubungan tetap resmi dengan komitmen waktu sedang. Karena salah satu peran media adalah publikasi dengan memberikan informasi program misalnya saat ada event dan promosi produk, maka adanya saling berbagi sumber daya yang minimal dan komitmen waktu yang sedang sesuai dengan peran yang dilakukan.

\section{Hubungan Akademisi Dengan Media}

Jenis hubungan antara akademisi dan media adalah merupakan networking. Networking merupakan satu-satunya jenis hubungan yang informasi dalam teori Robert yang berjudul Matrix of Stategies for Working Together. Hubungan ini menduduki tingkatan kerjasama yang paling bawah. Dimana komitmen waktu yang terjalin secara minimal dan tidak ada saling berbagi sumber daya. Fokus utama dalam hubungan ini yaitu pertukaran informasi. Karena tujuan utama media sebagai salah satu stakeholder yang berkontribusi dalam program ini adalah membantu program untuk berkembang secara optimal melalui peran yang dilakukan sesuai dengan tupoksinya. Akademisi tidak harus menjalin hubungan formal dengan media karena media lebih banyak terlibat secara langsung dalam publikasi kegiatan maupun promosi produk UMKM, sehingga akademisi dan media tidak memerlukan hubungan yang intensif.

\section{Hubungan Akademisi Dengan Komunitas}

Jenis hubungan antara akademisi dan komunitas adalah merupakan coordinating. Coordinating memiliki ciri komitmen waktu yang sedang, dan tidak ada atau minimal dalam hal saling berbagi sumber daya, hal ini sesuai dengan apa yang telah dikemukakan oleh Robert. Akademisi dan komunitas patut memiliki hubungan ini karena ciri-ciri tersebut sesuai dengan peran yang dilakukan. Dimana dalam hal ini akademisi tidak terlalu banyak bersinggungan dengan komunitas. Namun tetap harus menjalin hubungan secara formal dengan saling berbagi sumber daya secara minimal dan komitmen waktu yang sedang karena komunitas yang menaungi para pelaku UMKM.

\section{Hubungan Akademisi Dengan Bisnis}

Jenis hubungan antara akademisi dan bisnis adalah merupakan networking. Karena hubungan akademisi dan bisnis tidak harus secara formal. Salah satu ciri networking adalah pertukaran informasi menjadi fokus utama. Meskipun hubungan terjalin secara informal, saling bertukar informasi tetap diperlukan untuk mengembangkan program. Suatu program akan berkembang secara optimal jika kerjasama terjalin dengan baik dengan cara saling menjaga komunikasi antar stakeholder.

\section{Hubungan Media Dengan Bisnis}

Jenis hubungan antara media dan bisnis adalah merupakan networking. Networking merupakan hubungan yang terjalin secara informal. Dimana fokus utamanya adalah pertukaran informasi. Media dan bisnis tidak harus menjalin hubungan secara formal karena fokus media di sini adalah sebagai stakeholder yang mempublikasikan program dan produk-produk yang dihasilkan UMKM. 
Sehingga dengan adanya pertukaran informasi yang baik antara media dan bisnis sudah cukup untuk mendukung pengembangan program.

\section{Hubungan Komunitas Dengan Bisnis}

Jenis hubungan antara komunitas dan bisnis adalah merupakan collaborating. Komunitas dan bisnis perlu meningkatkan hubungan menjadi collaborating karena bisnis merupakan stakeholder yang berkontribusi dalam memberikan bantuan melalui pelatihan, bantuan modal, dan fasilitas. Sehingga komitmen waktu ekstensif dibutuhkan. Collaborating memiliki ciri saling berbagi sumber daya, risiko, tanggung jawab dan reward. Reward yang dimaksud disini bisa diartikan sebagai pemberian akses. Komunitas sebagai stakeholders yang menaungi para pelaku UMKM memerlukan akses untuk mempermudah proses bisnis, misalnya untuk memperoleh informasi bisnis.

\section{Hubungan Komunitas Dengan Media}

Jenis hubungan antara komunitas dan media adalah merupakan networking. Networking merupakan hubungan yang terjalin secara informal. Komunitas dan media tidak perlu memerlukan hubungan yang resmi untuk saling bertukar informasi. Ciri-ciri hubungan ini adalah tidak adanya saling berbagi sumber daya dan fokus utama hubungan ini adalah pertukaran informasi. Pertukaran informasi dibutuhkan untuk mengembangkan program agar berjalan dengan optimal. Media membutuhkan informasi untuk bahan publikasi. Sedangkan komunitas membutuhkan informasi untuk meningkatkan, memperbaiki maupun berinovasi dalam menjalankan peran dan kegiatan yang dilakukan.

Untuk melihat lebih rinci bagaimana pola hubungan dalam pengembangan UMKM dengan model pentahelix dapat dilihat pada gambar berikut:

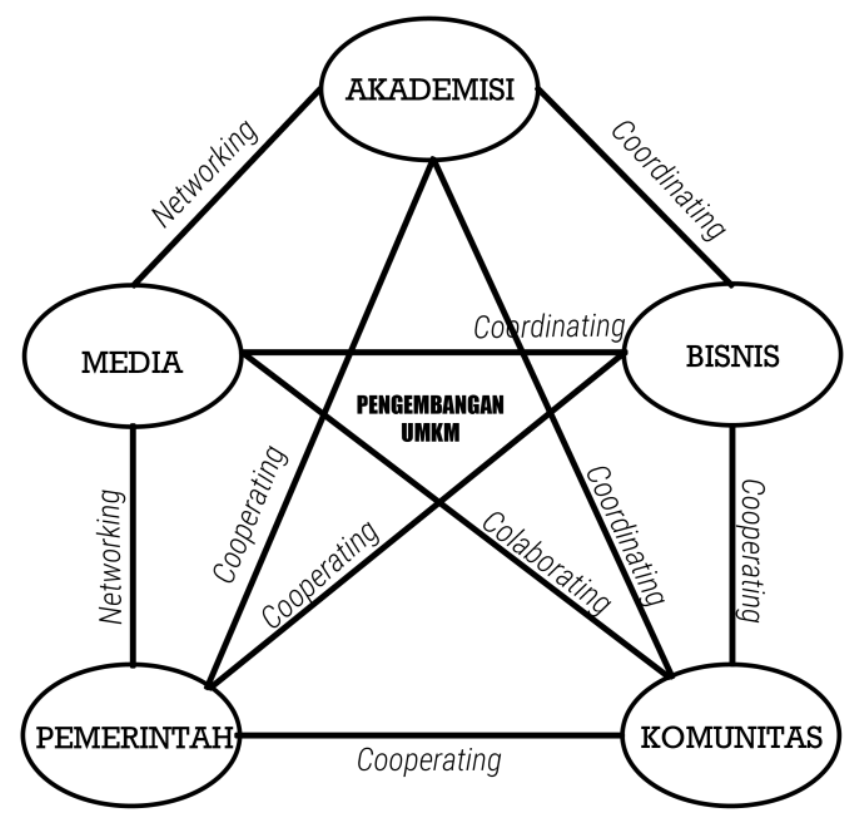

Gambar 1. Pola Hubungan Pengembangan UMKM Dalam Model Pentahelix 


\section{Kesimpulan Dan Saran}

Berdasarkan hasil penelitian yang telah dijelaskan maka dapat diambil kesimpulan bahwa dalam pengembangan UMKM di Kecamatan Wonosari menggunakan model pentahelix telah melibatkan lima stakeholders yaitu pemerintah, akademisi, komunitas, bisnis dan media. Meskipun lima stakeholders tersebut belum menjalankan perannya dengan optimal. Pemerintah menjalankan perannya sebagai fasilitator, regulator dan katalisator dengan cukup baik meskipun terkadang sasaran atas kebijakan pemerintah masih ada yang tidak tepat sasaran. Peran media massa yang belum optimal dan hanya ada ketika ada event juga perlu mendapatkan perhatian. Selain itu kemampuan sumber daya manusia juga perlu mendapatkan pelatihan dan pendampingan agar bisa memanfaatkan media sosial dengan baik tidak hanya menggunakan facebook tetapi juga bisa memanfaatkan platform lain seperti instagram, twitter dan website dalam mengembangkan usahanya. Pola hubungan yang terjalin antar stakeholders dalam model pentahelix ini beragam yaitu sebagai networking, coordinating, cooperating dan collaborating. Hal ini tergantung dengan hubungan yang terjalin antar stakeholder dan peran yang telah dilakukan. Para stakeholder menjalin hubungan dengan saling berbagi dalam bertukar informasi, sumber daya, risiko dan tanggung jawab untuk mencapai tujuan guna mengembangkan UMKM secara optimal.

Adapun yang masih menjadi kekurangan dalam model pentahelix ini adalah koordinasi antar stakeholder yang masih bersifat kondisional. Sehingga disarankan kedepan pemerintah yang merupakan leading sektor harus memperhatikan dan mempererat koordinasi anatar seluruh stakeholder, jika perlu hingga berkordinasi langsung dengan UMKM agar supaya kondisi ini tidak akan terjadi. Hal ini harus menjadi perhatian bagi pemerintah sebagai leading sektor untuk mengkoordinasikan seluruh stakeholder. Diperlukan adanya monitoring dan juga evaluasi karena dalam menjalankan program ini pemerintah belum melaksanakan monitoring dan evaluasi.

\section{Daftar Pustaka}

Aisyah, S. (2020). Dampak Pandemi COVID-19 Bagi UMKM Serta Strategi EMarketing UMKM di Indonesia. Journal of Chemical Information and Modeling, 53(9), 3-9.

Gede D. (2019). Mengembangkan UMKM Melalui Pemberdayaan... - Google Cendekia. Bakrie School of Management. https:/ / scholar.google.com/scholar?hl=id\&as_sdt=0\% 2C5\&q=Gede\%2C+D.+\% 2 $82009 \% 29$.+Mengembangkan+UMKM+Melalui+Pemberdayaan+Peran+Pemerint ah+Daerah+\%281st+ed.\%29.+Bakrie+School+of+Management.\&btnG=

Ilma; R. S. B. N. R. H. R. A. H. L. lu'ul. (2016). Strategi Pengembangan Ukm Digital Dalam Menghadapi Era Pasar Bebas. Jurnal Manajemen Indonesia, 16(2), 136. https://doi.org/10.25124/jmi.v16i2.319

Lekatompessy, E. M. R. (2020). Kolaborasi Model Pentahelix Dalam Pengembangan Pariwisata Berbasis Kearifan Lokal Di Kabupaten Merauke. Transparansi: Jurnal Ilmiah Ilmu Administrasi, 3(1), 55-63. https://doi.org/10.31334/transparansi.v3i1.866

Lexy j, M. (2017). No Metodologi Penelitian Kualitatif (Revisi). Pt. Remaja Rosdakarya.

Nurmalia, A. (2018). Strategi pengembangan usaha mikro, kecil, dan menengah (umkm) dengan model penta helix. Universitas Muhammadiyah Yogyakarta.

Pedoman Destinasi Pariwisata Berkelanjutan, 1 (2016).

Roberts, J. (2004). Partnerships: Building Collaborative Organizations. New Society 
Publisher.

Rodriguez;, H. A. S. S. R. O. M. R. L. (2017). The Penta Helix Model Of Innovation In Oman: An Hei Perspective. Interdisciplinary Journal of Information, Knowledge \& Management, 12, 159-174.

Santoso, A. P. S. (2019). Pemberdayaan Usaha Mikro, Kecil, dan Menengah Kerajinan Emas dan Perak Desa Pulo Kecamatan Tempeh Kabupaten Lumajang oleh Dinas Perdagangan.

Santoso, A. P. S. (2019). Pemberdayaan Usaha Mikro, Kecil, dan Menengah Kerajinan Emas dan Perak Desa Pulo Kecamatan Tempeh Kabupaten Lumajang oleh Dinas Perdagangan [Fakultas Ilmu Sosial Dan Ilmu Politik]. http:/ / repository.unej.ac.id/handle/123456789/97484

Saputri, Fa. W. (2020). Implementasi Model Pentahelix Dalam Pengembangan Pariwisata Studi Pada Talang Indah Fajaresuk Kab. Pringsewu. Jurnal Kompetitif Bisnis, 1(1), 7.

Soleha, A. R. (2020). Kondisi UMKM Masa Pandemi Covid-19 Pada Pertumbuhan Ekonomi Krisis Serta Program Pemulihan Ekonomi Nasional. Jurnal Ekombis, $6(2), 165-178$.

Sugiyono. (2018). Metodologi Penelitian Dilengkapi dengan Metode R\&D. Depublish.

Sukarmi. (2016). Perlindungan Desain Industri Bagi Umkm Yang Berkeadilan $\begin{array}{llll}\text { Sosial. Jurnal Pembaharuan Hukum, } & 97 .\end{array}$ https://doi.org/10.26532/jph.v3i1.1350

Sukirno, S. (2011). Makroekonomi: Teori Pengantar. PT.Raja Grafindo Persada.

Sutapa, M. (2014). Peningkatan Kapabilitas Inovasi, Keunggulan Bersaing dan Kinerja melalui Pendekatan Quadruple Helix: Studi Pada Industri Kreatif Sektor Fashion. Jurnal Manajemen Teknologi, 13(3), 304-321. https://doi.org/10.12695/jmt.2014.13.3.5

Veckie, A. M. T. E. V. V. W. (2015). Aplications Of Penta Helix Model In Economic Development. Economy of Eastern Croatia Yesterday, Today, Tommorow, 4, 385393. https://ideas.repec.org/a/osi/eecytt/v4y2015p385-393.html

Yunas, N. S. (2019). Implementasi Konsep Penta Helix Dalam Pengembangan Potensi Desa melalui Model Lumbung Ekonomi Desa di Provinsi Jawa Timur. Matra Pembaruan Jurnal Inovasi Kebijakan, 3(1), 37-46. https://doi.org/10.21787/mp.3.1.2019.37-46 